\title{
QUEEN'S
UNIVERSITY
BELFAST
}

\section{Protecting the most vulnerable in an economic crisis: a participatory study of civil society organisations in the Republic of Ireland}

Carney, G., Dundon, T., \& Ni Leime, A. (2012). Protecting the most vulnerable in an economic crisis: a participatory study of civil society organisations in the Republic of Ireland. Voluntary Sector Review, 3(3), 329346. https://doi.org/10.1332/204080512X658045

Published in:

Voluntary Sector Review

Document Version:

Peer reviewed version

Queen's University Belfast - Research Portal:

Link to publication record in Queen's University Belfast Research Portal

Publisher rights

(C) 2012 Policy Press

This is a post-peer-review, pre-copy edited version of an article published in Voluntary Sector Review. The definitive publisher-authenticated version Carney, G, Dundon, T \& Ni Leime, A 2012, 'Protecting the most vulnerable in an economic crisis: a participatory study of civil society organisations in the Republic of Ireland' Voluntary Sector Review, vol 3, no. 3, pp. 329-346., 10.1332/204080512X658045 is available online at: http://dx.doi.org/10.1332/204080512X658045

\section{General rights}

Copyright for the publications made accessible via the Queen's University Belfast Research Portal is retained by the author(s) and / or other copyright owners and it is a condition of accessing these publications that users recognise and abide by the legal requirements associated with these rights.

Take down policy

The Research Portal is Queen's institutional repository that provides access to Queen's research output. Every effort has been made to ensure that content in the Research Portal does not infringe any person's rights, or applicable UK laws. If you discover content in the

Research Portal that you believe breaches copyright or violates any law, please contact openaccess@qub.ac.uk. 


\title{
"Protecting the Most Vulnerable" in an Economic Crisis: A Participatory Study of Civil Society Organisations in Ireland ${ }^{i}$
}

\author{
Gemma M. Carney ${ }^{1}$ \\ Irish Centre for Social Gerontology, National University of Ireland Galway \\ Tony Dundon \\ J.E. Cairnes School of Business and Economics, National University of Ireland Galway \\ Áine Ní Léime
}

Irish Centre for Social Gerontology, National University of Ireland Galway

\begin{abstract}
This paper advances knowledge of roles played by Civil Society Organisations (CSO's) when negotiating the shift from boom time public expenditure to a programme of austerity. The study focuses on the Republic of Ireland, where CSOs occupy an important role in providing a voice for 'vulnerable' citizens in corporatism. A cadre of national umbrella organizations formed the Community and Voluntary Pillar (CVP) of the national system of corporatist bargaining, named 'social partnership', for over a decade. During the economic growth of the Celtic Tiger era (1994-2007), social partners worked together to produce welfare reform mirroring Ireland's economic success. However the global financial crisis and subsequent austerity measures meant the country's model of corporatist-style partnership collapsed. This article connects CSOs' adaptation to austerity measures when protecting the 'people behind the cuts' to broader questions about co-optation of civil society through state-led policy making institutions.
\end{abstract}

Keywords: participatory, civil society, co-optation, third sector

\section{Introduction}

This paper examines the work of Civil Society Organisations (CSOs) in protecting the 'people behind the cuts' under a programme of governmental imposed austerity. The paper contributes to international debates about roles played by CSOs in a variety of national, and increasingly transnational, contexts around the globe (Salamon, 2003; Taylor, 2003; Taylor, 2010). In liberal democratic states, third sectori $^{\mathrm{il}}$ or voluntary organisations act as an organized intermediary for some members of society. Children, people who are retired or unemployed, undocumented migrants, people with disabilities, and the homeless at times depend on CSOs to

\footnotetext{
${ }^{1}$ Corresponding author. Dr. Gemma Carney, Research Fellow, Irish Centre for Social Gerontology, J.E. Cairnes School of Business and Economics, NUI Galway. gemma.carney@nuigalway.ie
} 
advocate on their behalf (Schneider and Ingram, 1997; 2000; Evers and Laville, 2004; Pestoff, 1992). The conditions of citizens represented by participant organisations in this study could be described as 'excluded,' in the sense defined by Walker and Walker (1997: 8): 'the dynamic process of being shut out, fully or partially, from any of the social, economic, political and cultural systems, which determine the social integration of a person in society.'

The global crisis of capitalism of the early $21^{\text {st }}$ Century has exposed the need for democratic systems to ensure citizens can influence macro-economic governance. Extreme inequalities and high levels of risk have shown the need for political economies to ensure a sustainable distribution of resources across different groups in society (Crotty, 2012: 79). The most common governmental response to financial insecurity at the macro-level in Europe and the US has been programmes of austerity (Crotty, 2012). In a recession where all but the highest social classes have experienced increasing insecurity and unemployment groups that were vulnerable in more buoyant economic times are more likely to be affected by cuts to social protection. For groups rendered powerless by political exclusion and economic deprivation (Gaventa 1982), CSOs act as intermediaries, making their case to governments set on reducing public expenditure.

This paper focuses on Ireland, as one case where austerity has challenged CSOs that act as 'intermediate institutions' (Schneider and Ingram, 1997) protecting the most vulnerable from extreme deprivation. The research reported here makes a connection between the work of CSOs in protecting 'the people behind the cuts' and broader questions about the incorporation of civil society through state-led policy making institutions (Carins et. al., 2010: Elstub, 2006). The economic crisis and the subsequent collapse of Ireland's social partnership institution raised important research questions about CVP member organisations' independence, adaptability and resilience. It is these questions and the answers to them provided by our research that are considered here. The central issue is how CVP member associations would protect the interests of their constituents after the collapse of social partnership. The paper proceeds as follows: first, CSOs as intermediary institutions is considered, including their socio-political role in Ireland along with an explanation of social partnership and the potential for co-option within the machinery 
of State decision-making. The next section explains the methodological approach, Participatory Action Research (PAR), a design that promoted participant engagement. Next, the research evidence is presented, highlighting the resilience and adaptive capacity of CSOs in a recession. The implications of the data are then discussed, challenging the contention that CSOs had become incorporated. The paper concludes that the organisations studied here not only retained their independence but were capable of adjusting their strategic priorities through new and emergent tactics when social partnership collapsed.

\section{Social Partnership and CSO Incorporation.}

Placing the Third Sector in Ireland in an international context It is increasingly recognised that neither the State nor the market can fully meet the needs and wants of citizens and consumers (O'Hara in Borzaga and Defourney, 2001: 149). In some instances, it falls to non-governmental or not for profit organisations, often referred to as the 'third sector', to intervene. Evers and Laville (2004) point to three particular features of the third sector: the type of organisations involved; the intermediary nature of the roles they occupy; and the socio-political dynamics involved in decision-making processes at a macro level. CSOs navigate between institutions of social and political life adapting and transforming relations and contracts between state and citizen and between market and consumer. Notions like 'diversity' and 'hybridity' have been used to describe this role (Osborne, 2005). Buckingham (2010: 2) uses the concept of 'hybridity' to describe 'the increasing involvement of CSOs in government contracts.' Contemporary examples include the concept of the Big Society as articulated by the Conservative-led coalition government in the UK (Buckingham, 2010). CSOs have been the subject of scrutiny on accountability of management, involvement in decision-making, advocacy and representation in the quality of services delivered (Osborne, 2005; Cairns et al 2010; Keenan, 2008; Haugh and Rubery, 2011; Evers, 2005). Echoes of debates in this UK literature are explored in the discussion that follows of the Irish socio-political context for CSO engagement with the state.

Ireland: socio-political context

Pestoff's (1992) and Evers' (1990) notions of the 'third sector' take account of the tension for CSOs in negotiating advocacy and service delivery roles. In liberal 
democratic states, like Ireland, CSOs lobby government for services, sometimes providing those services (Carney and Scharf, 2011). Like other familial welfare systems, in Ireland the State plays a residual role in the form of poverty prevention or means-tested benefits and services (Saraceno, 2008). The system of social protection has been identified as a 'hybrid' system where a 'constellation of actors are involved in providing services ... from self-employed family doctors through notfor-profit church organisations to salaried public servants' (National Economic and Social Council, 2005: 35). The welfare system is noted for its 'resilience and capacity to adjust' - a characteristic which 'might not be forthcoming if it were a welfare state with more defined characteristics' (National Economic and Social Council, 2005: 35). In comparison with other European states, the Irish welfare state has been described as 'neoliberal and residual' (Timonen et. al., 2006). Deficiencies can be observed across care sectors. Family and market are most likely to provide childcare and many people subsidise their healthcare with private health insurance. At the end of $201147 \%$ of the Irish population had private health insurance (Department of Health, 2012). There are few rights to public services on the basis of social citizenship. These conditions make the presence and actions of lobby groups and CSO's in influencing the development of social policy all the more important in the Irish context.

The Irish system's weakness arises when particular subsets of citizens are inadequately represented by the institutions of democracy; there is potential for those who need services to have too little say in what is provided. Without a principle of universal entitlement, the role of CSOs as intermediaries is to promote access to services and protect the rights of their constituents. The study presented here engaged with one segment of this important sector of Irish society, the CVP as a formal collective constellation of CSOs within social partnership. The CVP comprises seventeen member organisations and provides a formal and structured mechanism for CSOs to input into and influence macro social and economic policy. While the CVP is only one segment of a large and vibrant third sector in Ireland (Keenan, 2008), it is an especially influential grouping as its members were signatories to the last three social partnership agreements over a period of fourteen years (Larragy, 2006). Proponents of participatory democracy criticise the inclusion of CSOs in strategic bargaining because negotiations took place behind closed doors (O'Carroll, 
2002). Gaynor (2011: 497), re-visiting interviews with some, but not all members of the CVP in 2005-2007 concludes that through participating in social partnership 'civic actors... have contributed toward a narrowing of the deliberative space within, but most particularly outside, this process.' Essentially, accepting an invitation for membership of the CVP led to tension between advocacy and civic roles identified by Evers and Laville (2004). Gaynor rightly concludes that the 'collective capacity' of 'civic associations' to maintain engagement with the state and broader civil society 'remains understudied' (Gaynor, 2011: 499).

The current study engaged with all seventeen member organisations of the CVP, thereby avoiding the omissions of earlier work, which had presented a Pillar view on the basis of selected interviews with key informants (Meade, 2005). Secondly, the research pioneered a methodology - Participatory Action Research (PAR) - that allowed for the analysis of strategic bargaining in social partnership without compromising the confidentiality of the process. The research was timely given that the last social partnership agreement, Towards 2016, collapsed. Since then, no empirical work had been undertaken to establish processes of CSO engagement through the State's apparatus of social partnership.

There are several important features to the particular arrangement in Ireland that affect the capacity of CSOs to influence outcomes for their constituencies. First, partnership is first and foremost a voluntary arrangement that was initially born out of an economic downturn and mass emigration in the mid-1980s. Government provided the infrastructural support for social partners to meet and enter into dialogue over macro-economic and social welfare policy objectives. A second important feature is that over time the range of the social partners widened to include a broader spectrum of stakeholders: government/civil servants, employer associations, trade unions, several CSOs who form the CVP, the farming community, charities and church leaders. Finally, in Ireland especially, social partnership was conceived during difficult times and was seen as a rallying call to engender a more cooperative national culture (Dobbins and Dundon, 2011). The first partnership agreement was signed in 1987 followed by an uninterrupted period of national bargaining, with the last agreement, Towards 2016 (2006), establishing formal plans for welfare reform and social policy through the Developmental Welfare State. Scholars have pointed to 
the role of social partnership as a key ingredient in Ireland's boom period (Hardiman, 2003). However, social partnership collapsed in 2010 when the government unilaterally introduced austerity measures by cutting public sector pay and social welfare to reduce public deficit and support a failing banking system (McDonough and Dundon, 2010).

The voluntarist dynamic of social partnership, rather than the more regulated models found elsewhere in Europe (e.g. Sweden or Germany, for instance), has important implications for the trajectory of CSO input into social and welfare policy decisions. In Ireland, social partnership has constituted a permissive system because it places few constraints on State agencies when decisions are reached (Dundon et al, 2007). In liberal market regimes such as Ireland, the idea that community bodies can contribute to welfare and tax expenditure for the constituency they represent goes against the grain of a deeply embedded mind set, where private corporations believe they have unilateral authority to make labour market decisions affecting others (McDonough and Dundon, 2010). Arguably, social partnership in Ireland, despite its linguistic and structural appeal for CSO's, actually places few constraints on the State or other decision-makers. For example, social partnership implies a sharing of 'risk' between labour stakeholders (Martinez-Lucio and Stuart, 2005). For groups who cannot access the labour market, such as retired people or children, these risks are considerably higher and the access to decision-makers more difficult than say, trade union or business leaders who are often privy to civil servants and decisionmakers through the social partnership arrangement. The implication was that there existed a hierarchy of pillars with power distributed downwards from government to employers and unions. Farmers and community and voluntary pillars occupy the bottom two rungs of the pecking order. Understanding the unequal distribution of risk in Irish society is central to unpacking the adaptability and/or resilience of CSOs to defend the interests of their constituency given the aftermath of economic austerity. It has been posited that CSOs would become incorporated into the State apparatus of decision-makers, thereby threatening the independent participation of CSOs in social welfare reform in Ireland (Meade, 2005). This aligns with a broader international debate, questioning the demise of 'community' in favour of market forces from the 1980s onwards (Taylor, 2003). Employing concepts like 'agora' to describe the grey area between public and private (Taylor, 2003; O'Carroll, 2002), 
that debate explores opportunities for community to emerge as a viable space for participation in social and political life. The current study is one of the first to document the next stage of that evolution of civil society, as it responds to perhaps the biggest crisis of capitalism in a century.

\section{The Question of Co-optation}

A rich literature exists analysing and evaluating the third sector and its usefulness to democracy (Cairns et. al., 2010; Taylor in Taylor, 2010: 240; Elstub, 2006). Literature specific to the Irish context is often critical of social partnership as a means of promoting participatory democracy (Larragy, 2006; Daly, 2007; Murphy and Teague, 2004; Meade, 2005; Gaynor, 2009, 2011). The argument is that the independence of the community sector has been compromised in order to promote a neo-liberal consensus (Allen, 2009; Meade, 2005). Questions around the role of community organisations in social partnership emerged following the negotiations of 2003-2004, when some CVP members became so disenchanted with partnership they withdrew from negotiations (Meade, 2005). It has been argued that because social partnership was where major social policy decisions were made, CSOs would find it impossible to remain critical given the power differentials between pillars. The stifling nature of corporatism would make it impossible for under-resourced CVP members to maintain independence. Related to this is a discussion as to who merits inclusion in the CVP (Meade, 2005); what defines membership of the broader community sector and whether civil society can remain independent given that the majority of CSO's are state-funded (Daly, 2007). Some of the most ardent critics of CVP engagement in social partnership view the 'signing up' of CSOs to the rules of the corporatist game as relinquishing control, as the agenda for CSOs is now set by government as a result of their membership of the CVP (Meade 2005). The risk of community engagement with the state becoming a public relations exercise is not unique to Ireland (Scholte 2001). Cairns et al. (2010; 194) identify similar views amongst voluntary and community organisations in Britain who 'take the view that power still lies very much in the hands of government agencies.'

\section{Impact of the Recession on Social Partnership}

At the time the research was conceived social partnership was the primary method for policy planning in Ireland. By the time the data were gathered, Irish corporatism 
had entered a period of stagnation as the government struggled to deal with a wave of economic crises (Carney et. al. 2011). CSOs were forced to re-orient their lobbying away from long-term social development strategies (National Economic and Social Council 2005), and towards intense political campaigns to halt cuts to social welfare payments under the government's programme of austerity (Callan, 2010). Strategic development of public services, income supports and activist measures changed to a basic plea to 'protect the vulnerable.' 'Protecting the vulnerable,' a term used by CSOs since 2008, was identified as a common focus for participants and researchers. As researchers, we sought to establish how CSOs protect the vulnerable in times of economic crisis. The following section reviews the role of PAR in facilitating this transition for the research.

\section{Methodology}

PAR is recognized for its capacity to draw coherent and holistic accounts of diverse, contested or hard to reach populations while supporting respondent engagement and ensuring empathy (Kemmis and McTaggart, 2000; Dundon and Ryan, 2010). In this study, the reflective aspect of PAR was useful as it enabled participant organisations to reflect on their reactions to a rapidly changing policy environment as the recession deepened (Carney et al, 2012). This paper concentrates on CSOs' narration of how their priorities and strategies adapted from one of implementing an agreed social reform programme to the more immediate task of protecting social welfare recipients during an economic crisis.

\section{Selection of participants}

The Community and Voluntary Pillar of social partnership is a highly diverse group of CSOs. The group of seventeen organizations formed a pillar on the invitation of successive governments, for over a decade. The organizations are diverse in ethos, membership, organizational structure, capacity and charitable status. Some are secular or church-led campaign and research organizations providing professional lobbying services for key constituents or on key issues such as poverty or gender inequality. Others are small, personality-driven organizations with few members. Still others are large charities that provide key services such as care or advocacy to vulnerable groups, outlined in table 1. 
Table 1: Member Organisations of the Community and Voluntary Pillar

\begin{tabular}{|c|c|c|}
\hline Name of Organisation & $\begin{array}{l}\text { Membership of } \\
\text { CVP }\end{array}$ & Description \\
\hline Age Action & $2003-4$ & Advocacy organisation for older people \\
\hline Carers Association & $2003-4$ & Advocacy organisation for family carers in the home \\
\hline Children's Rights Alliance & $2003-4$ & Umbrella organisation of children's rights groups \\
\hline Community Platform & Pre-2000 & $\begin{array}{l}\text { Umbrella organisation facilitating solidarity amongst } \\
\text { organisations in the Community \& Voluntary sector }\end{array}$ \\
\hline $\begin{array}{l}\text { Congress Centres for the } \\
\text { Unemployed }\end{array}$ & Pre-2000 & $\begin{array}{l}\text { Representative organisation for unemployed members of } \\
\text { trade unions }\end{array}$ \\
\hline $\begin{array}{l}\text { Disability Federation of } \\
\text { Ireland }\end{array}$ & $2003-4$ & Umbrella organisation for people with disabilities \\
\hline $\begin{array}{l}\text { Irish Council for Social } \\
\text { Housing }\end{array}$ & $2003-4$ & $\begin{array}{c}\text { National Federation representing social housing } \\
\text { organisations. }\end{array}$ \\
\hline $\begin{array}{l}\text { Irish National Organisation } \\
\text { of the Unemployed }\end{array}$ & Pre-2000 & Advocacy organisation for unemployed people \\
\hline $\begin{array}{l}\text { Irish Senior Citizens } \\
\text { Parliament }\end{array}$ & $2003-4$ & Advocacy organisation of older people \\
\hline Irish Rural Link & $2003-4$ & Campaigns for sustainable rural communities \\
\hline $\begin{array}{l}\text { National Association of } \\
\text { Building Cooperatives }\end{array}$ & $2003-4$ & Campaigns for Co-operative housing movement. \\
\hline National Women's Council & Pre-2000 & Umbrella organisation of women's rights groups \\
\hline $\begin{array}{l}\text { National Youth Council of } \\
\text { Ireland }\end{array}$ & Pre-2000 & Umbrella organisation for youth organisations \\
\hline Protestant Aid & Pre-2000 & Church of Ireland charity \\
\hline $\begin{array}{l}\text { Social Justice Ireland } \\
\text { (formerly CORI Justice) }\end{array}$ & Pre-2000 & Catholic (and lay) charity and think tank. \\
\hline $\begin{array}{l}\text { Society of St. Vincent de } \\
\text { Paul }\end{array}$ & Pre-2000 & $\begin{array}{l}\text { Catholic anti-poverty charity providing services and } \\
\text { advocacy }\end{array}$ \\
\hline The Wheel & $2003-4$ & Capacity building of C\&V sector \\
\hline
\end{tabular}

\section{Participatory Action Research Methods}

Participatory research methods allow researchers to build an alliance with participants, leading to the co-production of knowledge over a period of time (O'Reilly, de Brun and de Brun, 2009). In practical terms, researchers and participants meet on multiple occasions. The project's philosophy was to conduct a piece of action research that could offer a more complete picture of the complex, ongoing process of community engagement in corporatism. Initial contact with participants revealed high levels of research fatigue. The role of PAR in facilitating the recruitment of participants is elaborated elsewhere (Carney et al 2012). However, it is important to note that PAR aided the engagement and support with 
and between all seventeen diverse participant organisations. PAR offered two unique strengths. First, the fact that we engaged with participants using different methods on separate occasions allowed us to track both their initial response to the economic crisis (individual interviews) and how these led to adaptation of their strategies (group deliberations). Second, our philosophical commitment to aiding the research and development of the third sector led us to pursue a number of goals of benefit to participants. In particular, the main findings of the study were published in a report which was peer-reviewed by participants and presented to the government and policy-makers in May 2011. Table 2 outlines the process of engagement for the project.

Table 2: Participatory Modes of Engagement

\begin{tabular}{|c|c|c|c|}
\hline Timing & Method & Mode of Engagement & Purpose \\
\hline $\begin{array}{l}\text { July-September } \\
2009\end{array}$ & $\begin{array}{c}\text { Seventeen semi- } \\
\text { structured interviews }\end{array}$ & $\begin{array}{l}\text { Individual interviews } \\
\text { between one member of } \\
\text { research team and one } \\
\text { member of CVP } \\
\text { organisation. }\end{array}$ & $\begin{array}{l}\text { Provide information to } \\
\text { participants on an individual } \\
\text { basis and gather background } \\
\text { information to inform the } \\
\text { research design. }\end{array}$ \\
\hline December 2009 & $\begin{array}{l}\text { Information meeting } \\
\text { with at least on } \\
\text { member of staff from } \\
\text { each member } \\
\text { organisation of the } \\
\text { CVP }\end{array}$ & $\begin{array}{c}\text { Group meeting to which } \\
\text { all members of CVP } \\
\text { were invited. }\end{array}$ & $\begin{array}{l}\text { To provide information on } \\
\text { project, feedback from } \\
\text { interviews and demonstration } \\
\text { of research methods. } \\
\text { Brainstorming, grouping and } \\
\text { ranking in two groups of } \\
\text { seven. }\end{array}$ \\
\hline February 2010 & $\begin{array}{c}\text { Six group } \\
\text { deliberations } \\
\text { (children, older } \\
\text { people, cross-cutting } \\
\text { (x2), people with } \\
\text { disabilities and } \\
\text { people of working } \\
\text { age) }\end{array}$ & $\begin{array}{c}\text { Group meeting to which } \\
\text { all members of CVP } \\
\text { were invited. }\end{array}$ & $\begin{array}{l}\text { Brainstorming, grouping and } \\
\text { ranking in groups from } 2-6 \text {. }\end{array}$ \\
\hline March 2011 & $\begin{array}{l}\text { Meeting to review } \\
\text { draft of final report. }\end{array}$ & $\begin{array}{l}\text { Group meeting to which } \\
\text { all members of CVP } \\
\text { were invited. }\end{array}$ & $\begin{array}{l}\text { Presentation of research } \\
\text { findings to participants. } \\
\text { Discussion of plans for } \\
\text { dissemination. }\end{array}$ \\
\hline
\end{tabular}

PAR's reflective capacity in adjusting to the unfolding economic crisis Initial interviews with leaders of the seventeen CVP member organisations, held between July and September 2009, revealed that social partnership was 'on hold'. At interview, participants consistently referred to the economic crisis and how it caused social partnership to stall. The change of Taoiseach (Prime Minister) in May 2008 
and the onset of the global credit crisis later that year were seen as two precipitating factors in the expiration of social partnership. These interviews clearly changed the basis on which the project could proceed. The initial focus had been on children, older people and people with disabilities as they are identified within the 'lifecycle' framework in Towards 2016. As participatory researchers, our commitment to listen to participants' concerns led us to adjust the research question in order to capture the representation of vulnerable groups by CSOs after the collapse of the system of decision-making. In this way, the economic crisis opened up new research questions about the participant organisations' adaptability and resilience, and potentially threw light on the question of whether CSOs had been co-opted by the State. Our research now addressed two additional questions. 1) Given the economic crisis, what priorities do CSOs now have for vulnerable groups? 2) Given the impact of the crisis on social partnership, what strategies do CSOs now use to campaign on these priority issues? It is the answers provided to these questions that are presented as research results and considered in the discussion and conclusion of this paper. As we are interested in exploring how participants negotiated the move from boom to austerity, the findings presented in this paper are based on the seventeen individual interviews held with leaders of the CSOs in 2009, just as the Irish government began to formulate austerity as its response to the global economic crisis. We return to the interview data for one important reason. The timing of the interviews (July September 2009) means the data generated captured participants' views in the immediate aftermath of the crisis. In terms of understanding how CSOs demonstrated adaptability and resilience in responding to the crisis, interview data offer clear statements by participants on the extent to which their interests and concerns moved away from social partnership at times, towards direct political lobbying and protest on other occasions. It is worth noting that additional data on this matter is provided in the main research report (Carney et al 2011), which explicates differences in responses between groups such as children's rights activists, older people's lobbies and disability federations.

The interviews were subject to a thematic analysis using NVIVO software. Twentyfour thematic categories were generated, including protecting the vulnerable, impact of the recession, insider-outsider, role of social partnership, inclusion in decisionmaking, role of unions and informal dialogue between social partners. In order to 
provide a deeper analysis, only the first two categories: protecting the vulnerable and impact of the recession on CSOs' strategies are presented in this paper.

\section{Results}

Engagement with CSOs on multiple occasions over an 18 month period resulted in a large amount of evidence from interviews, group deliberations and review meetings demonstrating that CSOs adapted away from social partnership as it fell into dis-use. Nevertheless, CSOs remained loyal to their constituents regardless of the institutional structure favoured by government. This conclusion questions previous claims that CSOs had been co-opted by the State via social partnership. At group deliberations, participants were asked to identify key priorities for their constituents. All CSOs agreed on key priorities for constituents regardless of age, life stage, gender or ethnicity. These were access to services, participation in social and political life, right to health and well-being, and income protection. These priorities were not new, as a result of the recession, since many of the most socially and politically excluded groups in Irish society had remained poor throughout the boom. The onset of the recession did, however, cause CSOs to adjust the strategies they used to campaign on these priorities, outlined in Table 3. 
Table 3: Common Strategies Used by CSO's

\begin{tabular}{|c|c|c|}
\hline Strategy & Within Social Partnership & $\begin{array}{l}\text { Outside Social } \\
\text { Partnership }\end{array}$ \\
\hline $\begin{array}{l}\text { Communications and } \\
\text { Awareness Raising }\end{array}$ & $\begin{array}{l}\text { Relationship with media } \\
\text { negotiated as a pillar with } \\
\text { reference to social partnership } \\
\text { agreement. }\end{array}$ & $\begin{array}{l}\text { Increasingly using the } \\
\text { media to appeal directly to } \\
\text { the public, referred to as } \\
\text { 'awareness raising.' }\end{array}$ \\
\hline 'Making the Case' & $\begin{array}{c}\text { Research evidence presented to } \\
\text { civil servants via policy } \\
\text { submissions }\end{array}$ & $\begin{array}{l}\text { Anecdote and 'horror } \\
\text { stories' communicated } \\
\text { directly by constituents in } \\
\text { the media. } \\
\text { Media training of ordinary } \\
\text { members. }\end{array}$ \\
\hline Building Strategic Alliances & $\begin{array}{c}\text { Policy linkage groups on } \\
\text { housing, education etc. for } \\
\text { member organisations of CVP. } \\
\text { Membership of National } \\
\text { Economic and Social Council }\end{array}$ & $\begin{array}{l}\text { Broad based alliances and } \\
\text { campaigns on child and } \\
\text { fuel poverty with CSO's } \\
\text { from outside pillar. }\end{array}$ \\
\hline Using the Political System & $\begin{array}{l}\text { Lobbying civil servants via } \\
\text { membership of the pillar. }\end{array}$ & $\begin{array}{c}\text { Direct Lobbying of } \\
\text { politicians. } \\
\text { Raising issues at UN and } \\
\text { European Level. }\end{array}$ \\
\hline $\begin{array}{l}\text { Mobilisation of grass-roots } \\
\text { membership }\end{array}$ & Rarely used. & $\begin{array}{l}\text { Increasingly important, } \\
\text { referred to as a 'guerilla } \\
\text { tactic' and politics with a } \\
\text { small 'p.' }\end{array}$ \\
\hline
\end{tabular}

From 2009 onwards, strategies that could be categorized as 'outside social partnership' were more commonly employed. Some CSOs began to describe these as 'post partnership' strategies. The next section traces this change in strategies to the CSOs' realization, from early 2009, that the economic crisis had completely changed how social policy could be progressed. The remainder of the paper outlines how CSOs described this change of tactic, offering some detail on what these strategies tell us about the adaptability and resilience of CSOs in a crisis situation.

\section{Protecting the Most Vulnerable}

The idea of 'protection' emerged independently and repeatedly when participants were asked about the impact of the recession on their work. Their discourse around 'protection' took a number of different forms. For some, the immediate priority was to 'protect' benefits and social welfare rates. 'In the past we would have been very vocal about asking for increases... it isn't feasible now, but it has resulted in a real 
change - towards protection' (Interview, 2009: CVP6: 3). Some participants referred to specific examples of how particularly vulnerable groups could suffer multiple disadvantage where proposed cuts to a number of seemingly distinct services could, in reality, repeatedly disadvantage one section of society. 'there's a whole pile of things that don't have the disability bracket on them that are chawing (sic) away every week at people's capacity to make ends meet' (Interview, 2009: CVP17A: 11). CSOs link these everyday experiences of retraction of government funded programmes to the long-term need to protect gains already made. A particularly illuminating example was offered by the same interviewee in relation to the National Disability Strategy. Having successfully used the social partnership system to make disability an important governmental priority, disability lobbies now fear that years of work would be undone, in the name of austerity. As a result, protecting the disability strategy was their core aim at the time of interview: 'To protect the Disability Strategy, to keep it coherent and to make sure that it survives the recession, that it doesn't become an empty shell and that the investment that's gone into it isn't eroded' (Interview, 2009: CVP17A: 9). Similar themes of protection were expressed in relation to social housing, child benefit, carers' and pension payments.

\section{Impact of the Recession on CSOs' strategies of engagement}

While CSOs moved from progression to protection of social welfare rates in the recession, they also reported a number of strategic moves away from social partnership and towards other forms of lobbying, including political protests. Most were at pains to explain how the recession, while it had immediate impacts on the organisations themselves through cuts to the government grant for participation in social partnership, this had no impact on their commitment to protect the vulnerable. Conversely, a number of participants reported that an immediate impact of the recession was to 'galvanise' the Pillar into action. 'When there was lots of money it was every organization for themselves... around late December last year (2008) it became obvious we were in a different ball game, then I think things began to shift... there's been more coming out with one voice' (Interview, 2009, CVP15: 1).

As the extent of the global economic crisis became apparent, the CVP invested some time in assessing the situation, working together to form a coherent response to the cuts. Significantly, these CSOs began to shift their collective focus away from 
social partnership and towards more grass-roots style lobbying. One children's rights activist remarked: 'it (the recession) hasn't changed our policy issues. It has convinced us more and more of the need to empower others to lobby and advocate on their own behalf' (Interview, 2009, CVP12: 2). The swing away from strategic bargaining and towards more participatory forms of democratic engagement emerged repeatedly in interviews. The majority of participants also referred to a successful protest by older people when the government threatened in October 2008 to remove the automatic right of those over 70 to free primary medical care. The protest, (organised by two member organisations of the CVP), and the public reaction to it, were identified by one participant, a leader of the older people's lobby, as a vision of the future: 'This is a kind of groundswell we hope to develop over the years, where older people themselves are taking the lead and a hint of the future would be the famous church protest meeting last October...People were stunned by that "Good God, these old people are speaking for themselves"' (Interview, 2009, CVP19: 4). Related to this need for members of CSOs to speak directly to government was a keen recognition that solidarity across vulnerable groups must be maintained. 'Now, the danger is competing armies and any government would be able to divide a group... older people, younger people, disability groups, carers and so on' (Interview, 2009, CVP19: 4).

Community development and advocacy work were seen as particularly susceptible to funding cuts, something which government could easily justify to the public: 'there's a really strong feeling, oh look we've been spending far too much money on all this - on welfare, on community organisations - there's a backlash' (Interview, 2009, CVP16: 1). In response, participant organisations made many efforts to undertake cost-benefit analysis, or to devise clear and easily digestible statistics which would use the same utilitarian language so effectively employed by those proposing austerity. However, CSOs seem very aware of the short-termism of many elements of the austerity programme. Much concern was expressed about the possibility that cross-spectrum cuts to government programmes could undo many of the gains that had been made for their constituents over past decades. In fact, from their perspective, community was never more important: 'We feel the community infrastructure is crucial at this time to maintain social cohesion. At this kind of time for 
society, we need a strong infrastructure there and we're afraid it is going to be eroded' (Interview, 2009, CVP7: 1).

CSOs demonstrated a high degree of tacit knowledge on two fronts. First, in terms of their understanding of the complexity of priority issues for constituents. Second, in the broad range of strategies they use and how adaptive they are. A key issue for all CSOs was the efforts needed to hold government to promises made before the economic crisis. During periods of economic growth, it was easier to get government to pay attention to demands. Since the onset of the crisis, economic concerns had taken precedent and any long-term social planning was on hold (Interview, 2009, CVP13; 2). CSO's have had to change tactics, from monitoring government commitments in the Towards 2016 agreement, to 'protecting the vulnerable' through campaigning against cuts to social welfare benefits.

During the time this study was conducted, many participant organisations formed coalitions to protect the vulnerable, taking unilateral action where necessary. At interview, almost every participant linked the political protest by older people in October 2008 (mentioned above) to the fact that the state pension was one of the few social welfare payments not to be cut in subsequent budgets. This experience has led many CSOs to reconsider how to expend their time and resources, perhaps favouring direct action in future. One member of the older people's lobby remarked: 'We will still have to represent our members to government but it won't be through social partnership. We'll be back to the grass roots, guerrilla warfare maybe' (Interview CVP 10, 2009).

\section{Discussion}

This research used PAR to examine how groups vulnerable to political and/or social exclusion are represented by CSOs. Our study showed that CSOs can and do function as potentially influential agency able to 'protect the vulnerable', using not only state-sponsored institutions but, more importantly, their own resourcefulness and strategic alliances under a programme of austerity. This capacity points to two important channels of influence hitherto undeveloped in the extant literature and 
theory. First is how the sudden death of corporatist decision-making demonstrated the adaptability, resilience and independence of CSOs that had hitherto been viewed as incorporated. The second related distinctive contribution is in connecting this capacity of CSOs to adapt to broader debates in the literature on co-optation. These two issues are briefly discussed next.

\section{Adaptability and Resilience of Civil Society Organisations}

Many of the CSOs studied here were founded before social partnership was established. Those with large memberships seem likely to survive any change of regime. However, it is unlikely that this resilience would have been captured had the research been conducted in less turbulent times. Most striking is the CSOs' demonstrated capacity to adapt to the changing socio-political context, given that only a few years previously, social partnership had even been considered as 'the only game in town?' for civil society in Ireland (Murphy, 2002). Leading activist Murphy (2002: 89) concluded that despite limited evidence of gains, 'the outsiders on the inside' should stay in the CVP. Interestingly, our study broadly concurs with Murphy's (2002) conclusion that the relationship between CVP and state is nuanced. More recently, Gaynor's comparative analysis of CSO engagement in social partnership in Ireland and Malawi (2009: 317) concluded that government funding provided to CSO's to participate in social partnership amounted to an 'inducement to dissenting partners.'

Our data, gathered in 2009-10 show a number of counter indications to the cooptation thesis. Firstly, there are a large number of influential community and voluntary organisations that are not members of the CVP. Therefore, there is an engaged community sector that was never part of social partnership. Some of the largest organisations supporting children and older people, Barnardo's, the Alzheimer's Society of Ireland and Third Age, are not members of the CVP. Rather, we argue, our use of participatory action research to undertake research with (as distinct from on) CVP members gave more nuanced results. We conclude that the economic crisis has led to CVP members 'realising their strategic importance' (Gaynor, 2009: 317), demonstrated by their prioritisation of constituents needs over social partnership status from 2009 onwards. 
Secondly, findings from this study suggest that some of the member organisations of the CVP are fully aware of costs and benefits of insider-outsider status: 'The success of the $\mathrm{C}$ and $\mathrm{V}$ sector is as both an inside activator and an outsider agitator..... some people can only yell from the outside, they don't see that being on the inside you can still change things' (Participant in Disability Stage group deliberation). Organisations studied are clear that they must 'work both sides of the equation' to achieve change. This is in line with research conducted in eight different national contexts (Gaventa and McGee, 2010). In capturing the collective experience of CVP membership our study revealed coalition building, resilience and tenacity of CSOs in adapting to boom-bust politics and economics. These findings echo Cairns et. al $(2010 ; 203)$ who found that when funding was cut, CSOs continued to find 'space and opportunity' to pursue advocacy goals. While government and other pillars might have superior bargaining resources, when it came to a severe and sudden recession, the less bureaucratic organizational styles of CSOs means they survive. While governments may be replaced through electoral processes, CSOs continue to work, though in straightened financial circumstances.

Our finding that CSOs returned to direct action mirrors the resurgence of grassroots organization in the United States of America, as documented by Skocpol (2011). Our study belongs to a burgeoning literature analyzing the third sector as part of a global system (Taylor, 2010), and perhaps one of the first to document CSO negotiation of the challenges of a global economic crisis.

\section{Conclusion}

In economic retrenchment, CSOs show greater longevity and resilience than either decision-making institutions (social partnership) or tri-partite led policies (Towards 2016). CSO members remained focused on promoting the agenda of their constituents, arguably limiting the effects of some of the largest government cuts to health and social welfare since the foundation of the Irish State in 1922. The research demonstrates the importance of investing in CSOs, who provided a legitimizing function to democracy when faced with global economic instability. This is not to suggest that CSOs could halt government cuts to social welfare rates. Indeed quite the reverse is evident: the people CVP organizations purport to 
represent have been shouldered a greater share of government cutbacks in social protection than other sections of the population. Nonetheless, CSO organizations were able to articulate, with varying levels of strategic purpose, the interests of their constituents by accessing civil servants and government ministers, using the media to raise awareness and through the formation of strategic alliances with CSOs outside social partnership. In itself that signifies considerable resourcefulness when faced with unprecedented cutbacks and the potential demise of the infrastructural stability afforded through the previous decades of social partnership.

The dynamic role of the CSOs studied here represents a vital link in understanding the evolution of democratic institutions. Member organisations of the CVP display a range of techniques to extract maximum resources from the state for their constituents - in this case children, older people, people with disabilities and the working poor amongst others - albeit as junior partners in a neo-liberal model of corporatism (Taylor in Taylor, 2010; 240). The developing role of CSOs in representing the interests of excluded groups in the context of increasingly underfunded welfare states deserves deeper investigation. In particular, further comparative analysis such as Gaynor's (2009) is needed. Studies asking why CSOs adopt particular strategies in response to specific circumstances (such as economic crisis or loss of legitimacy in state sponsored corporatism) offer challenging programmes of research for future third sector scholars.

The long-term challenge to improve accountability in the voluntary sector remains. Related to this is the need for international research and development to improve the capacity of CSOs to act as genuinely participatory, if not representative, institutions of democracy. Further research is needed to work with CSOs to improve their credibility as important 'intermediate institutions' of democracy (Schneider and Ingram, 1993). The use of participatory methods and a commitment by researchers to question not just the voluntary sector, but its pivotal role in representing socially and politically excluded groups, is the first step in developing a genuinely emancipatory research agenda for this increasingly important, dynamic 'third sector' of the global democracy project. 


\section{Acknowledgements:}

This research was funded by the Irish Research Council. Thanks are due to research participants, Camille Loftus for outstanding research assistance, Mary O'Reilly de Brun and staff and students in the Economics Department at National University of Ireland Galway. Special thanks to Eamon O'Shea and Christine de Largy. Thanks to two anonymous reviewers for careful reading and suggestions. Gemma Carney would like to thank Neil, Callum and Ray Briscoe for good humour.

\section{References}

Allen, K. (2009) Ireland's Economic Crash: a radical agenda for change Dublin: Liffey Press.

Buckingham, H. (2010) 'Hybridity, Diversity and the division of labour in the third sector: what can we learn from homelessness organisations in the UK?' Third Sector Research Centre, working paper No. 50. at (web ref).

Cairns, B., Hutchinson, R. and Aiken, M. (2010) 'It's not what we do, it's how we do it': managing the tension between service delivery and advocacy' Voluntary Sector Review, 1 (2) pp. 193-207.

Carney, G. and Scharf, T. (2011) 'The Role of the Community and Voluntary Sector in Planning the National Positive Ageing Strategy' Dublin: Older \& Bolder.

Carney, G., Dundon, T. and Ni Leime, A. (2012) ' Participatory action research with and within community activist groups:capturing the collective experience of Ireland's Community and Voluntary Pillar in social partnership Action Research Journal at http://ari.sagepub.com/content/early/2012/07/18/1476750312451279.abstract

Carney, G., Dundon, T., Ni Leime, A and Loftus, C. (2011) Community engagement in Ireland's Developmental Welfare State: a study of the life cycle approach. Irish Centre for Social Gerontology, NUI Galway.

Crotty, J. 2012. "The great austerity war: what caused the US deficit crisis and who should pay to fix it?," Cambridge Journal of Economics, Oxford University Press, vol. 36(1), pages 79-104

Daly, S. 2007. Mapping civil society in the Republic of Ireland. Community Dev J 43 (2): 157-176.

Department of Health and Children (2012) 'Private Health Insurance in Ireland' available at http://www.dohc.ie/about us/divisions/ppp health ins.html. Downloaded July 24, 2012.

Dobbins, T and Dundon, T. (2011) 'Workplace Partnership and the Future Trajectory of Employement within Liberal Market Economies', in A. Wilkinson and K. Townsend (eds) The Future of Employment Relations. Basingstoke: Palgrave Macmillan. Dundon, T and P. Ryan (2010), 'Interviewing Reluctant Respondents: Strikes, Henchmen and Gaelic Games' Organizational Research Methods, Vol 13 (3): 562581.

Dundon, T., Gonzalez-Perez, M. and McDonough, T. (2007), 'Bitten by the Celtic Tiger: immigrant workers and industrial relations in the new "Glocalised" Ireland, Economic and Industrial Democracy, Vol 28 (4):501-522

Donoghue, F., Anaheier, H. and Salamon, L. M. (1999) 'Ireland' in Salamon, L. M. et al. (1999) Global Civil Society: Dimensions of the Nonprofit Sector Baltimore, MD, John Hopkins Center for Civil Society Studies.

Elstub, S. (2006) 'Towards an inclusive social policy for the UK: the need for democratic deliberation in voluntary and community associations,' Voluntas, 17 (1): pp. 17-39. 
Evers, A. and Laville, J-L. (2004) 'Defining the third sector in Europe' in Evers, A. and Laville, J-L. (eds) The Third Sector in Europe London: Edward Elgar.

Gaventa, J. 1982. Power and powerlessness: quiescence and rebellion in an Appalachian Valley. Chicago: Universty of Illinois.

Gaventa, J. and McGee, R. . 2010. Citizen Action and National Policy Reform: making change happen. London: Zed Books.

Gaynor, N. (2009) 'Deepening democracy within Ireland's Social Partnership' Irish Political Studies, 24, No. 3, 303-319.

Gaynor, N. (2011) 'Associations, Deliberation and Democracy: the Case of Ireland's Social Partnership' Politics \& Society, 39: 4, 497-519.

Haugh, H. and Rubery, E. (2005) 'Educating managers to lead community enterprises' International Journal of Public Administration, 28, No. 9, 887-902. Hardiman, N. (2003) 'Politics and markets in the Irish 'Celtic Tiger' experience: choice, chance or coincidence?' Institute for the Study of Social Change: UCD Howlin, B. (2011) 'BUDGET 2012: Statement of the Minister for Public Expenditure and Reform' Irish Times, December 5, 2011. (available at http://www.irishtimes.com/indepth/budget2012/speeches/brendan-howlin.html downloaded July, 24 2012).

Keenan, O. (2008) 'Relationships and Representation, Challenges and Opportunities for the Voluntary and Community Sector in Ireland' (at: http:

www.middlequarter.com).

Kemmis, S. and McTaggart, R. (2000) 'Participatory Action Research' in Denzin, N. K. and Lincoln, Y. S. (eds). Handbook of Qualitative Research Second Edition, New Delhi: Thousand Oaks.

Larragy, J. (2006) 'Origins and Significance of the Community and Voluntary Pillar in Irish Social Partnership' Economic and Social Review, 37, No. 3, 375-398.

Callan, A. (ed). Budget Perspectives 2010 Dublin: ESRI Research Series Number 12, October 2009.

McDonough, T. and Dundon, T. (2010), 'Thatcherism delayed? The Irish crisis and the paradox of social partnership', Industrial Relations Journal, 41 (November): 544562.

Meade, R. 2005. We hate it here, please let us stay! Irish social partnership and the community/voluntary sector's conflicted experiences of recognition. Critical Social Policy 25 (3): 349-373.

National Economic and Social Council (2005) The Developmental Welfare State. Dublin: Stationary Office.

O'Hara, P. (2001) 'Ireland: social enterprises and local development' in Borzaga, C. and Defourny, J. (eds.) The Emergence of Social Enterprise London: Routledge. O'Carroll, J. P. (2002) 'Cultural lag and democratic deficit in Ireland: Or Dat's Outside de terms of D'Agreement' Community Development Journal Vol 31 (1) January 2012, pp. 10-19.

O'Reilly de Brun, M. and de Brun, T. (2009) 'The Use of Participatory Learning and Action (PLA) Research in Inter-cultural Health: some examples and some questions' Translocations: migration and social change. An inter-disciplinary open access ejournal ISSN: 2009-0420.

Osborne, S. P. (2005) 'Voluntary Action in a Changing Europe: critical perspectives' International Journal of Public Administration, 28, No. 9, 733-735.

Pestoff, V. A. (1992) 'Third Sector and Co-operative Services - an alternative to privatisation' Journal of Consumer Policy 15: 21-45. 
Salamon, L. M. (2003) The Resilient Sector: the state of nonprofit America Washington: Brookings Institution Press.

Saraceno, Chiara (ed.), (2008) Families, Ageing and Social Policy. Intergenerational Solidarity in European Welfare States, Cheltenham: Edward Elgar.

Schneider, A. and Ingram, H. . 1997. Policy Design for Democracy. Kansas:

University of Kansas.

Schneider, A., and H. Ingram. 1993. Social Construction of Target Populations Implications for Politics and Policy. American Political Science Review 87 (2): 334347.

Scholte, Jan Art. 2001. "Civil Society and Democracy in Global Governance." 65/01. University of Warwick.

Skocpol, T. and Williamson, V. (2011) The Tea Party and the Remaking of Republican Conservatism NY: Oxford University Press.

Stuart, M and Martinez-Lucio, M. (2005). Partnership and Modernisation in Employment Relations. London: Routledge.

Taylor, M. (2003) Public Policy in the Community Basingstoke: Palgrave MacMillan. Taylor, M. (2010) 'Transforming Democracy?' in Taylor, R. (ed). Third Sector Research New York: Springer.

Taylor, R. (2010) 'Moving Beyond Empirical Theory' in Taylor, R. (ed). Third Sector Research New York: Springer.

Timonen, V., Cahill, S. and Convery, J. (2006) 'Care revolutions in the making? A comparison of cash-for-care programmes in four European countries'. Ageing \& Society, 26, No. 3,455-474.

Walker, A. and Walker, C. (eds.) (1997) Britain Divided: the growth of social exclusion in the 1980s and 1990s. London: Child Poverty Action Group.

\footnotetext{
' The phrase, 'protecting the most vulnerable' is used throughout this paper, and in the title, as it was coined by study participants in response to government cutbacks. Participants made a plea to 'protect the most vulnerable' and 'the people behind the cuts' in budget submissions from the onset of austerity in 2008. Their efforts were reflected in the fact that government pledged to 'protect the most vulnerable' in subsequent budgets (Howlin, 2011).

ii There are a variety of terms used to describe organisations of citizens including non-governmental, not for profit, third sector, voluntary, community. Throughout this paper we use the term to civil society organisation to refer to any non-governmental, not for profit organisation which occupies what Evers (1990) classically referred to as the 'third sector.'
} 